\title{
Abrupt changes in deep Atlantic circulation during the transition to full glacial conditions
}

\author{
David J. R. Thornalley, ${ }^{1,2}$ Stephen Barker, ${ }^{1}$ Julia Becker, ${ }^{1,3}$ Ian R. Hall, ${ }^{1}$ and Gregor Knorr ${ }^{4}$ \\ Received 21 August 2012; revised 19 December 2012; accepted 27 February 2013; published 30 May 2013.
}

[1] Six Ocean Drilling Program (ODP) sites, in the Northwest Atlantic have been used to investigate kinematic and chemical changes in the "Western Boundary Undercurrent" (WBUC) during the development of full glacial conditions across the Marine Isotope Stage 5a/ 4 boundary $(\sim 70,000$ years ago). Sortable silt mean grain size $(\overline{S S})$ measurements are employed to examine changes in near bottom flow speeds, together with carbon isotopes measured in benthic foraminifera and \% planktic foraminiferal fragmentation as proxies for changes in water-mass chemistry. A depth transect of cores, spanning $1.8-4.6 \mathrm{~km}$ depth, allows changes in both the strength and depth of the WBUC to be constrained across millennial scale events. $\overline{S S}$ measurements reveal that the flow speed structure of the WBUC during warm intervals ("interstadials") was comparable to modern (Holocene) conditions. However, significant differences are observed during cold intervals, with higher relative flow speeds inferred for the shallow component of the WBUC ( $\sim 2 \mathrm{~km}$ depth) during all cold "stadial" intervals (including Heinrich Stadial 6), and a substantial weakening of the deep component $(\sim 3-4 \mathrm{~km})$ during full glacial conditions. Our results therefore reveal that the onset of full glacial conditions was associated with a regime shift to a shallower mode of circulation (involving Glacial North Atlantic Intermediate Water) that was quantitatively distinct from preceding cold stadial events. Furthermore, our chemical proxy data show that the physical response of the WBUC during the last glacial inception was probably coupled to basin-wide changes in the water-mass composition of the deep Northwest Atlantic.

Citation: Thornalley, D. J. R., S. Barker, J. Becker, I. R. Hall, and G. Knorr (2013), Abrupt changes in deep Atlantic circulation during the transition to full glacial conditions, Paleoceanography, 28, 253-262, doi:10.1002/palo.20025.

\section{Introduction}

[2] Ocean circulation helps regulate global climate by redistributing heat, dissolved nutrients and carbon dioxide between the atmosphere, surface, and deep ocean. A critical mechanism linking these reservoirs is the Atlantic Overturning Meridional Circulation (AMOC), in which deep water formed in the high latitude North Atlantic is rapidly transported into the ocean interior [e.g., Dickson and Brown, 1994]. Much of this transport occurs via the "Western Boundary Undercurrent" (WBUC) [Stommel, 1958; Swallow and Worthington, 1961; Dickson and Brown, 1994; Johns et al., 1997; Stahr and Sanford, 1999; Bower

Additional supporting information may be found in the online version of this article.

${ }^{1}$ School of Earth and Ocean Sciences, Cardiff University, Cardiff, UK.

${ }^{2}$ Department of Geology and Geophysics, Woods Hole Oceanographic Institute, Woods Hole, Massachusetts, USA.

${ }^{3}$ Institute for Meteorology and Climate Research (IMK-ASF), Karlsruhe Institute of Technology (KIT), Karlsruhe, Germany.

${ }^{4}$ Alfred Wegener Institute, Bremerhaven, Germany.

Corresponding author: D. J. R. Thornalley, Department of Geology and Geophysics, Woods Hole Oceanographic Institute, Woods Hole, MA, USA. (d.thornalley@cantab.net)

(C2013. American Geophysical Union. All Rights Reserved. 0883-8305/13/10.1002/palo.20025 and Hunt, 2000], a deep western boundary current that flows at depth along the eastern continental margin of North America and transports $\sim 16-19 \mathrm{~Sv}$ of deep-water (below $6^{\circ} \mathrm{C}$ ) southwards at $32^{\circ} \mathrm{N}$ [Stahr and Sanford, 1999]. The deep WBUC is fed by two main sources: mid-depth waters, formed by convection in the Labrador Sea, found at $\sim 1500-2500 \mathrm{~m}$ (Labrador Sea Water, LSW), and deep overflow waters from the Nordic Seas, found at $\sim 2500-4000 \mathrm{~m}$ depth, often termed "lower North Atlantic Deep Water" [Dickson and Brown, 1994; Stahr and Sanford, 1999; Bower and Hunt, 2000]. Collectively, these water masses are termed "North Atlantic Deep Water" (NADW), which at present ventilates much of the world's oceans and helps control its physical and chemical properties [Gebbie and Huybers, 2011]. Below $\sim 4000 \mathrm{~m}$, the modern WBUC also contains a small $(\sim 16 \%)$ proportion of recirculating Southern-Sourced Water (SSW) [Stahr and Sanford, 1999].

[3] To develop our understanding of the climate system, it is important to disentangle the response of the WBUC to glacial-interglacial shifts and superposed abrupt millennialscale climate change. The transition from Marine Isotope Stage (MIS) 5a to MIS 4 ( 70,000 years ago (70 ka)) is an ideal interval to achieve this goal because not only did it define the transition to full glacial conditions but it also witnessed multiple large millennial-scale climate events, termed "Dansgaard-Oeschger" (D-O) Events. Geochemical 


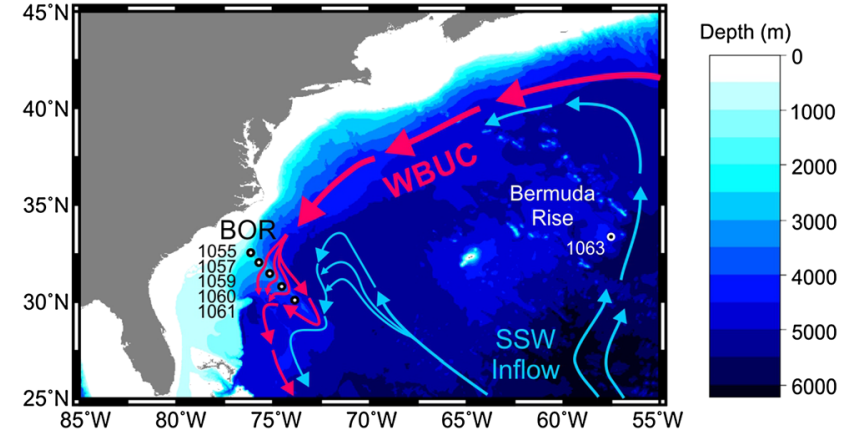

Figure 1. Schematic of the deep circulation of the Northwest Atlantic based on Stahr and Sanford [1999] and Weatherly and Kelley [1984], also showing ODP site locations. BOR, Blake Outer Ridge; SSW, Southern Source Water; WBUC, Western Boundary Undercurrent.

work has revealed that the transition into MIS 4 was likely accompanied by a reduction in the export of NADW to the deep South Atlantic [Piotrowski et al., 2005]; however, the precise timing and nature of the circulation change within the North Atlantic, including the behavior of the WBUC, remains uncertain.

\section{Regional Setting and Previous Work}

[4] Blake Outer Ridge (BOR, Figure 1) is a constructional sedimentary drift located in the western North Atlantic Ocean $\left(28^{\circ} \mathrm{N}-32^{\circ} \mathrm{N}\right)$ formed by the interaction of the deep contour-following WBUC with the northward flowing Gulf Stream as it detaches from the continental shelf [Stahr and Sanford, 1999]. Elevated sedimentation rates across the BOR, often in excess of $30 \mathrm{~cm} / \mathrm{kyr}$, facilitate high resolution paleoclimate reconstruction. Modern hydrographic data show that the high-velocity core of the WBUC is located on BOR at $\sim 3-4 \mathrm{~km}$ depth (i.e. within water derived from the Nordic Seas overflows), with a secondary fast flowing core at $\sim 1-2.5 \mathrm{~km}$, within LSW [Johns et al., 1997; Stahr and Sanford, 1999]. Sediment sorting by near-bottom currents associated with the WBUC enables grain-size analysis to be used to examine past changes in the strength and location of the WBUC; this approach has been tested using core-top depth transects taken on BOR [Haskell and Johnson, 1993; Evans and Hall, 2008]. Early studies examined various size ranges of the terrigenous silt fraction, but following McCave et al. [1995], who argued that only the $10-63 \mu \mathrm{m}$ component of the terrigenous silt fraction is current-sorted, paleocurrent reconstruction studies at BOR have largely focused on the application of the "sortable silt" mean grain size $\overline{S S}$ proxy [e.g., Evans and Hall, 2008].

[5] Down-core grain-size studies have revealed that the flow-strength of the WBUC underwent changes in both time and space (depth), on millennial and orbital timescales [Ledbetter and Balsam, 1985; Johnson et al., 1988; Haskell et al., 1991; Bianchi et al., 2001; Yokokawa and Franz, 2002; Evans et al., 2007; Hoogakker et al., 2007; Hall and Becker, 2007; Evans and Hall, 2008; Hall et al., 2011]. Silt grain size [Haskell et al., 1991] and $\overline{S S}$ depth transects [Yokokawa and Franz, 2002; Evans and Hall, 2008] have demonstrated that the fast-flowing core of the WBUC at BOR is located deeper than $\sim 3 \mathrm{~km}$ during interglacials, and shoals to $\sim 2.5 \mathrm{~km}$ or less during glacials. Yet similar studies have not been conducted throughout the last glacial cycle, which notably includes the high-amplitude, abrupt, climate changes associated with D-O events. Silt grain size data [Johnson et al., 1988] and SS records from Evans et al. [2007] and Hoogakker et al. [2007] have been used to investigate flow speed variability at BOR throughout MIS 3-5, revealing millennial-scale changes in near-bottom flow speed over BOR. However, because these studies were limited to only one or two core sites, the full spatial response of the WBUC to D-O events has yet to be constrained, and it therefore remains unclear to what extent the WBUC is coupled to D-O climate variability. In this study, we build upon earlier investigations [Yokokawa and Franz, 2002; Evans et al., 2007; Hoogakker et al., 2007; Hall and Becker, 2007; Evans and Hall, 2008; Hall et al., 2011] by presenting high-resolution $\overline{S S}$ records from a depth transect of cores across the MIS 5a/4 transition spanning $1.8-4.6 \mathrm{~km}$ depth, enabling us to fully constrain changes in both the strength and depth of the WBUC. In doing so, we develop our understanding of the response of the WBUC to D-O events, and compare and contrast these results with other changes associated with the development of full glacial conditions.

\section{Materials and Methods}

[6] In this study, we provide new insight into the behavior of the WBUC during MIS 5a/4 using the "sortable silt" mean grain size $(\overline{S S})$ proxy [McCave et al., 1995; McCave and Hall, 2006] in cores from BOR (Figure 1). Variability in the $\overline{S S}$ proxy reflects relative changes in the intensity of the near-bottom current through selective deposition and removal, with coarser mean values representing more vigorous near-bottom current speeds and vice versa [McCave et al., 1995; McCave and Hall, 2006]. We pair our $\overline{S S}$ data with chemical proxies that provide information on past water mass chemistry: records of the \% fragmentation of planktic foraminifera act as a proxy for carbonate dissolution, and benthic foraminiferal $\delta^{13} \mathrm{C}$ (Cibicidoides species) can be used to reconstruct past changes in the $\delta^{13} \mathrm{C}$ of dissolved inorganic carbon (DIC) in seawater [e.g., Curry and Oppo, 2005]. In the North Atlantic, incursion of nutrient-rich, corrosive SSW generally results in higher $\%$ fragmentation and low $\delta^{13} \mathrm{C}$, whereas a dominance of nutrient-depleted (high $\delta^{13} \mathrm{C}$ ), relatively noncorrosive NADW allows better preservation and lower $\%$ fragmentation.

[7] We use sediment cores recovered from BOR during Ocean Drilling Program (ODP) Leg 172 (Figure 1). Because the abyssal depths of BOR ( 4.5 km and below) are adversely affected by sedimentary mud waves [Flood, 1994; Yokokawa and Franz, 2002], we also include data from ODP Site 1063 located on Bermuda Rise (BR), in the deep central Northwest Atlantic. Whereas sedimentation at sites from BOR is controlled by the WBUC, sedimentation at BR is instead characterized by resuspension of sediment along its flanks as a result of the fast geostrophic flow of recirculating SSW along steep slopes, and deposition of the resuspended sediment on the plateau. Erosional features on the scarp caused by presumed episodes of stronger currents may correspond with intensified deep water circulation during glacials [McCave et al., 1982], when the NADW/SSW 
likely shoaled. Downcore changes in grain size at BR may therefore detect variability in recirculating SSW. We have produced high resolution data from three sites (Site 1055, $1.8 \mathrm{~km}$; Site 1059, $3.0 \mathrm{~km}$; and Site 1063, $4.6 \mathrm{~km})$ and supplemented these with previously published as well as new data from intervening Sites $1057(2.6 \mathrm{~km}), 1060$ $(3.5 \mathrm{~km})$, and $1061(4.0 \mathrm{~km})$, described in Table 1 . The ODP splice was used for all sites.

[8] Initial sample preparation and grain size analysis followed established procedures [McCave and Hall, 2006]. $\overline{S S}$ analyses were conducted on a Coulter Counter Multisizer III; data shown are the mean of at least two analyses, each sizing 70,000 particles (average RSD $\sim 0.7 \%$ ). Because of the coarse nature of some of the samples, particular care was taken to always ensure particles remained in suspension during analysis by using a fast stirrer setting (setting 35-40). Comparison between sites is achieved by normalizing the grain size in each record to its long-term mean value, which accounts for any down slope biasing of the signal (sites more distal from sediment sources may have a more limited range of grain sizes available for sorting, although this effect is thought to be minimal at BOR [Evans and Hall, 2008]) and the dependence of the local geostrophic flow velocity on seafloor bathymetry [Haskell et al., 1991; McCave and Hall, 2006; Hall et al., 2011].

[9] Samples of monospecific planktonic foraminifera, typically consisting of $8-50$ shells, were picked for stable isotope analysis for use in age model construction. We preferentially analyzed Globigerina ruber (white), but dissolution of $G$. ruber in deeper cores necessitated the use of the ubiquitous Globorotalia inflata. Typically, 2-10 benthic foraminifera were picked for benthic stable isotope analysis. Cibicidoides lobatulus and Cibicidoides wuellerstorfi were available for analysis at Site 1055, while at Site 1059/JPC37 we used C. wuellerstorfi data. The scarcity of $C$. wuellerstorfi at Site 1063 meant stable isotope analyses were conducted on samples of mixed Cibicidoides. Stable isotopes were analyzed at Cardiff University using a Finnigan MAT-252 mass spectrometer with Kiel II carbonate device (for samples $<80 \mu \mathrm{g}$ ) and a Delta V Advantage mass spectrometer with gas bench (for samples $>80 \mu \mathrm{g}$ ), calibrated to Vienna Pee Dee Belemnite. Longterm analytical precision is $\pm 0.08 \%$ for $\delta^{18} \mathrm{O}$ and $\pm 0.06 \%$ o for $\delta^{13} \mathrm{C}$.

[10] The \% fragmentation was calculated based on the number of fragments and whole shells of planktonic foraminifera in the $>150 \mu \mathrm{m}$ fraction, counted in a split containing $>300$ entities.

\section{Chronology}

[11] Initial identification of the MIS 5a/4 transition was based on published age models [Grüztner et al., 2002] that were constructed by orbital tuning of the weight \% carbonate (estimated using color reflectance data [Giosan et al., 2001]). MIS 4 can be identified in Northwest Atlantic Ocean records as a minimum in \% carbonate [Keigwin and Jones, 1994]. All cores were placed on a more tightly-constrained, common chronology by tuning to one another using planktic $\delta^{18} \mathrm{O}$ (Figures 2 and 3; G. ruber for Sites 1055, 1057, and 1059; G. inflata for 1055, 1061, and 1063). For Sites 1060 and 1061 , where planktic $\delta^{18} \mathrm{O}$ was either unavailable or of 


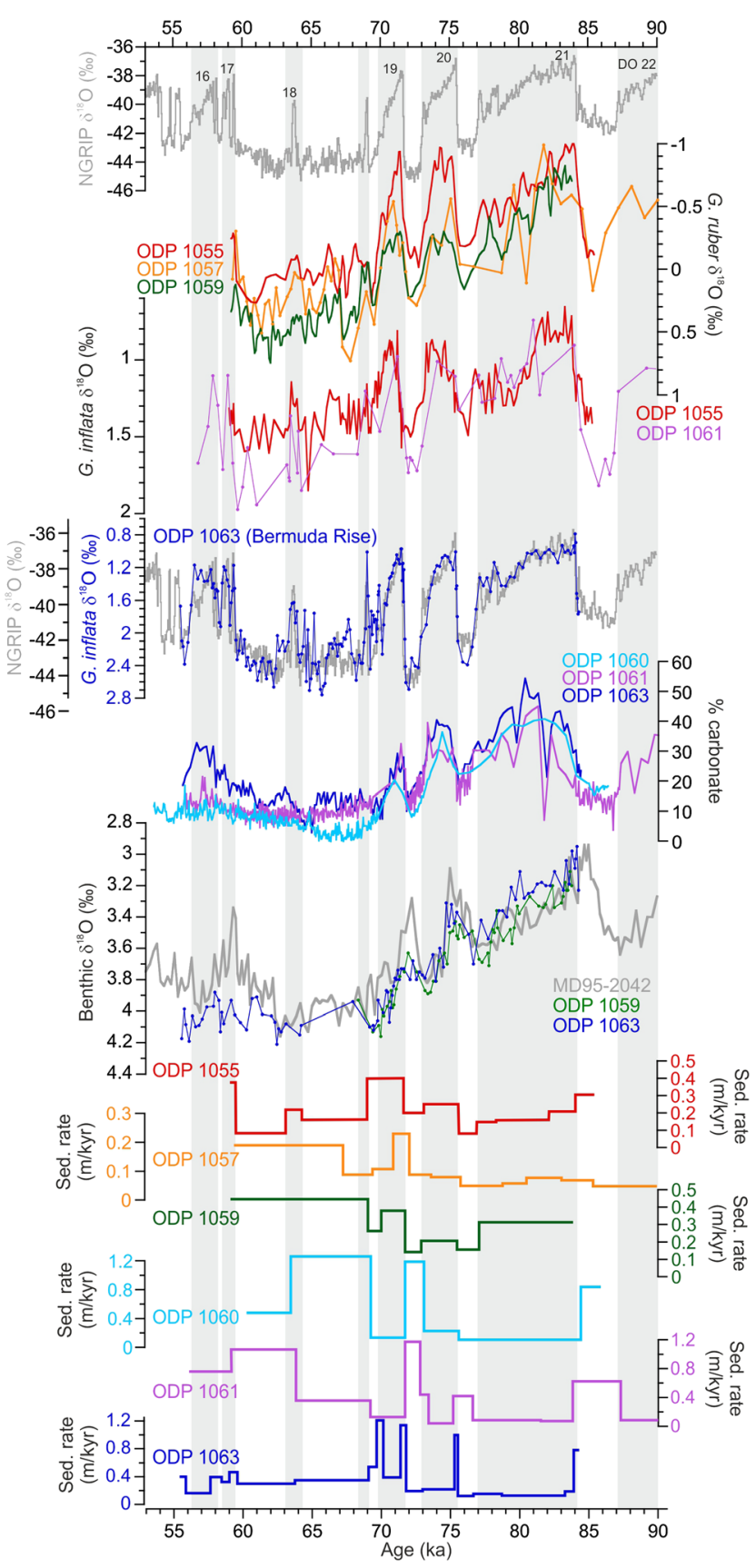

Figure 2. Age model construction for the cores based on tuning of planktic $\delta^{18} \mathrm{O}$ and \% carbonate [Giosan et al., $2001]$ records to abrupt changes in NGRIP $\delta^{18} \mathrm{O}$ [NGRIP members, 2004]. The age model for ODP 1060 for ages $<63 \mathrm{ka}$ is based on the existing tuning of faunal assemblage shifts to Greenland temperature [Vautravers et al., 2004], while for ages $>63 \mathrm{ka}$, it is based on tying the $\%$ carbonate to the \% carbonate record of ODP 1063 (for which high resolution G. inflata $\delta^{18} \mathrm{O}$ was tuned to NGRIP $\left.\delta^{18} \mathrm{O}\right)$. Planktic $\delta^{18} \mathrm{O}$ data for ODP 1057 is from Evans et al. [2007]; benthic $\delta^{18} \mathrm{O}$ for the Iberian Margin core MD95-2042 is from Shackleton et al. [2000]; all other stable isotope data are from this study. The abrupt, transient, increases in sedimentation rate at Site 1063 are likely caused by deposition of locally reworked sediment, further discussed in the supporting information (Figure S3).
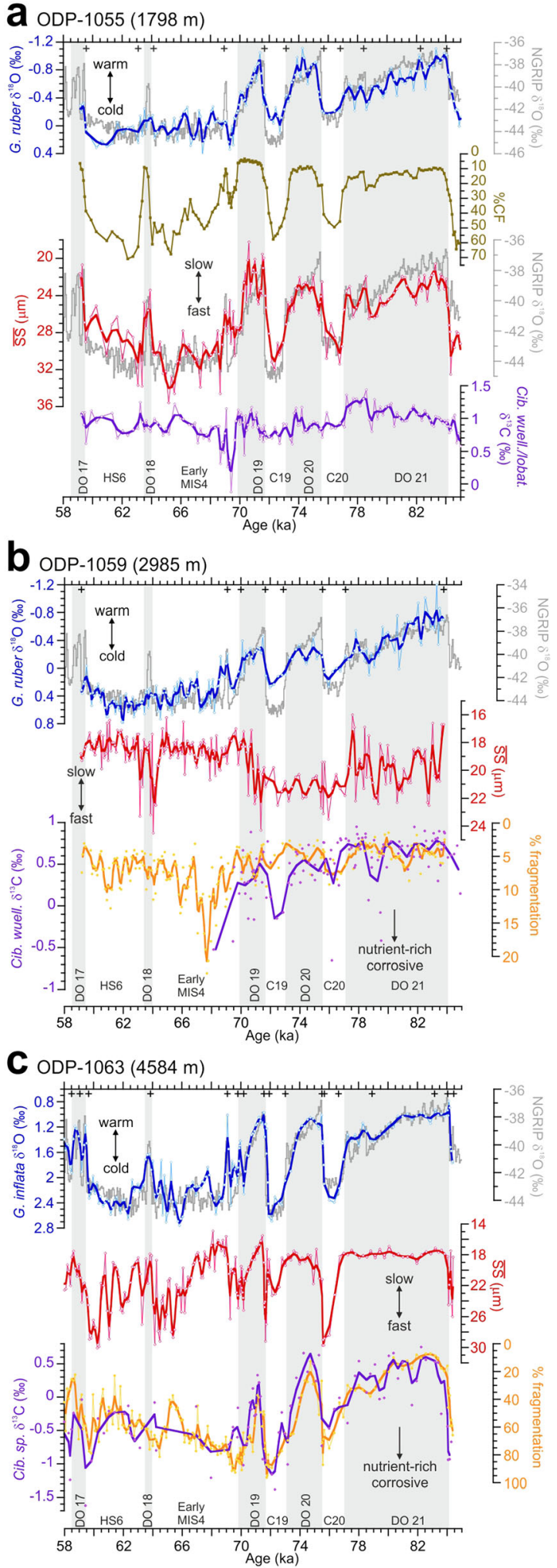

Figure 3. $(\mathrm{a}-\mathrm{c})$ Data from the three core sites studied at high resolution. \% coarse fraction $(\% \mathrm{CF})$ in Figure $3 \mathrm{a}$ is the dry weight percent $>63 \mu \mathrm{m}$. Bold lines indicate 3-point running mean, except for C. wuellerstorfi $\delta^{13} \mathrm{C}$ data from Site 1059/JPC-37 where we have used a 500-year smoothing of the combined datasets from this study, Evans et al. [2007] and Hagen and Keigwin [2002]. Black crosses indicate age model tie-points. 
low resolution, we tuned the high resolution percent carbonate records [Giosan et al., 2001] to that of Site 1063 following, for example, Keigwin and Jones [1994] and more recently, Gutjahr and Lippold [2011]. Inferred sedimentation rates linearly interpolated between age tie-points are shown in Figure 2, and the age tie-points are listed in the supporting information.

[12] G. ruber is a surface dweller, calcifying in the upper mixed layer, whereas $G$. inflata is a deeper, thermocline dweller [e.g., Cleroux et al., 2007], and therefore calcifies in underlying subtropical mode waters (formed regionally during winter mixing). It is therefore possible that offsets in the timing of $\delta^{18} \mathrm{O}$ shifts across abrupt climate changes may exist between the two foraminiferal species. However, previous work, for example, by Keigwin and Jones [1989], at BR has shown that abrupt shifts in both G. ruber and $G$. inflata $\delta^{18} \mathrm{O}$ are recorded at the same time by both species at this locality. To increase confidence in our use of the $G$. inflata $\delta^{18} \mathrm{O}$, we present paired stable isotope measurements on $G$. ruber and $G$. inflata from Site 1055 at BOR, which show that abrupt shifts in planktic $\delta^{18} \mathrm{O}$, in response to D-O variability across MIS 5/4, are recorded at essentially the same time by both species at this locality (Figure 2).

[13] The common chronology of all marine cores used in this study was then placed on a Greenland ice-core age scale by further correlating the abrupt shifts in planktic $\delta^{18} \mathrm{O}$ to similar events in North Greenland Ice Core Project (NGRIP) $\delta^{18} \mathrm{O}$ [NGRIP members, 2004], using the GICC05 timescale for $0-60 \mathrm{ka}$, and a speleothem-tuned age model prior to $60 \mathrm{ka}$ [Barker et al., 2011]. Abrupt shifts in planktic $\delta^{18} \mathrm{O}$ (both for G. ruber and G. inflata) in the Northwest Atlantic and Greenland ice core $\delta^{18} \mathrm{O}$ have been observed to be synchronous within radiocarbon-dated intervals [e.g., Keigwin, 1996; Keigwin and Boyle, 1999; McManus et al., 2004]. Further support for this correlation is provided by model results [e.g., Vellinga and Wood, 2002; Knight et al., 2005; Stouffer et al., 2006], alkenone-based sea surface temperature (SST) reconstructions from Bermuda Rise [Sachs and Lehman, 1999] (although the validity of these results has since been questioned [Ohkouchi et al., 2002]), faunal assemblage changes on BOR [Vautravers et al., 2004; Hoogakker et al., 2007], and Mg/Ca-based SSTs from Cariaco basin [Lea et al., 2003]. Although planktic $\delta^{18} \mathrm{O}$ from the subtropical Northwest Atlantic during D-O events likely contains both temperature and salinity signals, the "raw" planktic $\delta^{18} \mathrm{O}$ appears in phase with Greenland climate, at least on multi-centennial and longer timescales [Schmidt et al., 2006]. Moreover, the good agreement between our deep Northwest Atlantic benthic $\delta^{18} \mathrm{O}$ data and the Shackleton et al. [2000] benthic $\delta^{18} \mathrm{O}$ record from the Iberian Margin (also on a Greenland age-scale) provides additional support for the robustness of our chronology. We are therefore confident that the age models are sufficiently accurate to examine the millennial-scale D-O events associated with the MIS $5 \mathrm{a} / 4$ transition.

[14] Across the abrupt D-O events of MIS 5/4, where there are large shifts in planktic $\delta^{18} \mathrm{O}$, we consider it likely that the chronology for our high resolution cores (Sites 1055, 1059, and 1063), relative to the timing of events in Greenland, is accurate to within around \pm 500 years, based on the duration of the climate transitions in Greenland and our cores, and typical sampling resolution of 100-250 years. There is increased uncertainty for Sites 1057, 1060, and 1061, where we have relied on lower resolution planktic $\delta^{18} \mathrm{O}$ and tuning of percent carbonate, although the D-O events are easily identified. Therefore, it is likely that the relative uncertainty of our age model (with respect to the NGRIP record) is less than \pm 1000 years across these events. It is also worth noting that regardless of the absolute chronology used, the deep water proxies within each core can be directly related to their respective planktic $\delta^{18} \mathrm{O}$ records, which reflect changes in surface conditions in the Northwest Atlantic. Furthermore, in our time-slice depth-transects of inferred flow speed changes, where possible, we have avoided averaging data points that lie close to abrupt transitions, which helps negate some of the uncertainty in age model construction and also limits any potentially adverse artifacts caused by bioturbation, including the influence of variable biodiffusivities related to the particle size of the proxy carrier [e.g., Bard, 2001; Hall et al., 2010].

\section{Results and Discussion}

[15] Sortable silt mean grain size results from Site 1055 show that bottom current flow speeds at $1.8 \mathrm{~km}$ depth on the BOR are strongly coupled to planktic $\delta^{18} \mathrm{O}$, and by inference Greenland climate, with faster inferred flow speeds during D-O stadials and MIS 4 (Figure 3a). Changes in the weight percent coarse fraction $(\% \mathrm{CF},>63 \mu \mathrm{m})$ provide further support for the relationship between flow speed and climate, with high \%CF values (indicating winnowing of fine material by strong currents at this core site; see supporting information) during stadial intervals and MIS 4 (60-70\%).

[16] Chemical proxy data from the deepest core, Site 1063, also show strong D-O type variability. The $\%$ fragmentation and $\delta^{13} \mathrm{C}$ records at Site 1063 (Figure 3c) suggest a strong influence of well-ventilated, northernsourced deep waters during D-O interstadials (D-O 21, 20, and 19), with incursion and vigorous recirculation of SSW (inferred from $\overline{S S}$ ) occurring during stadials. The abrupt shifts in benthic $\delta^{13} \mathrm{C}$ and $\%$ fragmentation at the onset of $\mathrm{D}-\mathrm{O}$ interstadials suggest rapid deepening of NADW at these times, consistent with earlier findings [Keigwin et al., 1994; Keigwin and Jones, 1994] and similar behavior during millennial scale events of the last deglaciation [Keigwin et al., 1991; Robinson et al., 2005; Barker et al., 2010; Roberts et al., 2010]. The combined observations from Sites 1055 and 1063 demonstrate a link between North Atlantic climate, physical circulation at $1.8 \mathrm{~km}$ depth, and deep ocean chemistry during MIS 5a/4.

[17] Yet similar D-O variability is not observed in flow speed or chemical proxies at Site 1059; instead a step-like change in flow speed is observed at the onset of MIS 4 at this site (Figure $3 b$ ). The benthic $\delta^{13} \mathrm{C}$ data also suggest significant entrainment and recirculation of SSW during C19 and at the onset of MIS 4, after which Cibicidoides are no longer present. The $\%$ fragmentation data indicate that the most corrosive bottom waters appeared during early MIS 4 .

\subsection{Coupled Changes in Climate and WBUC Flow Speed Structure}

[18] The contrasting $\overline{S S}$ trends between different sites draw attention to the difficulty in fully assessing WBUC circulation changes using a single core (changes in flow speed at a single site could reflect variations either in the speed or vertical position of the current). To gain a more complete 

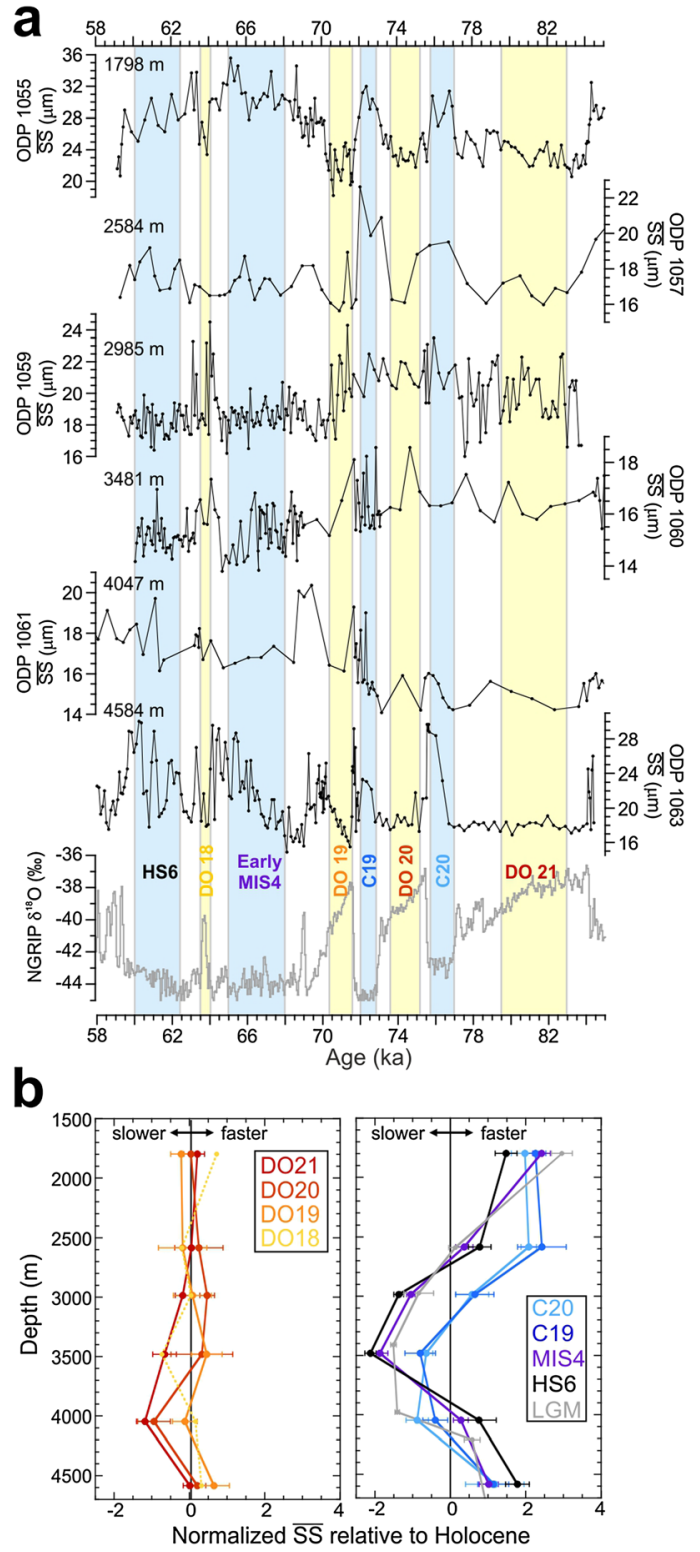

Figure 4. (a) Down-core $\overline{S S}$ data for BOR cores (ODP Sites 1055-61) and BR (ODP Site 1063) shown with NGRIP $\delta^{18} \mathrm{O}$ for reference. Note that the $\overline{S S}$ axes are reversed compared to those in Figure 3. Shading indicates the time intervals used to calculate the average values used in the time slice depth transects shown in (Figure 4b). Time intervals were centered on D-O events recorded in NGRIP $\delta^{18} \mathrm{O}$; the results are largely insensitive to the specific time interval chosen-see supporting information for sensitivity tests. (b) Normalized SS data plotted relative to normalized Holocene values, i.e., subtraction of normalized Holocene values. Data for the Holocene and LGM are from nearby BOR cores [Evans and Hall, 2008; Hall et al., 2011 and new unpublished data], normalized using data spanning the LGM-Holocene $(\sim 5-21 \mathrm{ka})$. Errors in the mean values shown in Figure $4 \mathrm{~b}$ are \pm 1 standard errors $(\mathrm{SE}=\sigma$ / $\sqrt{ }_{n}$; where $\sigma$ is the standard deviation and $n$ the number of observations), but as the validity of $\sigma$ reduces with decreasing $n$, we have substituted the half-range $\mathrm{R} / 2(\mathrm{R} / 2 \sqrt{\mathrm{n}})$ when $n<5$. For D-O 18 , the limited number of samples (typically $\mathrm{n}=1-3$ ) prevented meaningful calculation of standard error estimates. and coherent picture of WBUC dynamics, ideally we must use cores from several depths.

[19] Figure 4 shows $S S$ data compiled from several core sites to illustrate how the near-bottom flow speed structure of the WBUC has varied between different climate periods. Absolute values for changes in the flow strength are not shown because there is no universal calibration of $\overline{S S}$ versus flow speed [Ledbetter, 1986; McCave and Hall, 2006]. Instead, Figure 4 reflects whether flow speed increased or decreased at a particular depth, relative to Holocene values (Figure 4b). Based on the grain size data presented here, the following changes can be inferred:

[20] (1) During D-O interstadials (D-O 21, 20 and 19), the flow speed structure of the WBUC was similar to the Holocene, with perhaps a slight weakening at $4 \mathrm{~km}$ depth (Results for D-O 18, which are similar to other D-O interstadials, are shown for completeness, yet because this is such a short interstadial, which may not be fully captured by all cores and for which we have few data points, our results are less certain and we avoid further discussion of this interval).

[21] (2) During D-O stadials 19 and 20 (C19 and C20), flow speeds decreased slightly at $\sim 3.5-4 \mathrm{~km}$, while a substantial increase is observed at depths shallower than $\sim 3 \mathrm{~km}$ depth. Flow speeds increased at $\sim 4.5 \mathrm{~km}$.

[22] (3) During MIS 4 (including Heinrich Stadial 6 (HS6)), flow speeds weakened at $\sim 2.5-3.5 \mathrm{~km}$ depth and faster flow is inferred for depths shallower than $2.5 \mathrm{~km}$. We also observe that, although a slight weakening of flow speed occurred at $\sim 1.8 \mathrm{~km}$ during HS6, flow speeds were still high and caused sediment winnowing, i.e., ocean currents were very much active during this Heinrich stadial (Figure 3a). Faster flow speeds are recorded below $\sim 4 \mathrm{~km}$ depth. The inferred flow speed structure of the WBUC during MIS 4 (and HS6) was broadly similar to that reconstructed for the Last Glacial Maximum (LGM) and earlier glacial periods [Haskell et al., 1991; Yokokawa and Franz, 2002; Evans and Hall, 2008].

[23] The sensitivity of these results to changes in the selected time intervals was examined by averaging data spanning the full climate intervals (i.e., from mid-point of abrupt warming to mid-point of abrupt cooling) versus averages from much more restricted intervals (typically $\sim 500-800$ years; smaller intervals are not appropriate because of the decreasing number of data-points used for averaging) (Figure S2). These sensitivity tests revealed that the findings remain robust, regardless of the precise time interval over which we average the data (see supporting information).

\subsection{Vigorous Abyssal Recirculation of SSW During Stadials}

[24] Results from ODP 1063 ( 4.5 km, Bermuda Rise; supported by somewhat similar trends in ODP 1061, $\sim 4.0 \mathrm{~km}$, BOR; Figure 4a) demonstrate that there was vigorous deep recirculation of SSW in the Northwest Atlantic during stadial events of MIS 5a and throughout much of MIS 4 . The very pronounced changes in flow speed at Site 1063 across D-O events are likely caused by variation in the NADW/SSW interface: during stadials, when the NADW/SSW boundary shoals, vigorous recirculating SSW exerts a dominant influence on near-bottom flow speeds at Site 1063. During interstadials, the more sluggish flow at Site 1063 is presumably also related to the fact that the 
inflow of NADW into the basin occurs as a WBUC which does not directly affect Bermuda Rise, located in the center of the North American basin.

[25] Similar observations of vigorous SSW flow have been made during the LGM and HS1 from the Northwest Atlantic [Evans and Hall, 2008; Hall et al., 2011] although the picture from the Southwest Atlantic during glacial periods is less clear [e.g., Ledbetter and Johnson, 1976; Ledbetter, 1986; Masse et al., 1994]. More vigorous inflow of SSW has been reported during glacial intervals into the Southwest Pacific [Hall et al., 2001]. Consistent with these studies, geochemical proxies also suggest relatively rapid advection of SSW into the North Atlantic [Robinson et al., 2005; Negre et al., 2010] during the LGM and HS1. Model studies predict an increase in the production of Antarctic Bottom Water (AABW) during glacial periods, typically as a response to shifts in atmospheric circulation and sea-ice transport in the Southern Ocean [e.g., Shin et al., 2003; Schmittner, 2003]. Therefore, it is possible that vigorous recirculation of SSW in the deep Northwest Atlantic during stadials/glacial periods reflects stronger production of $\mathrm{AABW}$, although further research is clearly warranted.

\subsection{A Shift in Circulation Regime at the Onset of MIS 4}

[26] The flow speed depth profiles presented in this study (Figure 4), based on $\overline{S S}$ data, show that a circulation regime existed during MIS 4 that was quantitatively distinct from cold stadial intervals during MIS 5a. Circulation variability during MIS 5a was characterized by D-O stadialinterstadial oscillations, involving shoaling of the WBUC (with faster flow at depths $<3 \mathrm{~km}$ ) and incursion of SSW at depth during stadials. These changes can be viewed as a shoaling of the AMOC, and may be explained by shifts in the main locus of open ocean convection. Previous data [e.g., Sarnthein et al., 2000; Kissel et al., 2008] and modeling studies [e.g., Ganopolski and Rahmstorf, 2001; Oka et al., 2012] have shown that during stadials, deep convection weakened in the Nordic Seas (reducing the strength of the overflows feeding the WBUC at $\sim 2.5-4 \mathrm{~km}$ ), while open-ocean convection south of the GreenlandScotland Ridge strengthened, influencing depths $<3 \mathrm{~km}$. Moreover, because Greenland climate is sensitive to the locus of deep-water formation (either to the north or south of the Greenland-Scotland Ridge) [e.g., Ganopolski and Rahmstorf, 2001], the proposed mechanism would explain the inferred close covariance between Greenland temperature and our flow speed record at $1.8 \mathrm{~km}$ depth.

[27] A different circulation style is observed during MIS 4 compared to the interstadial-stadial regime of MIS 5a. During MIS 4, flow speeds at $2.5-3.5 \mathrm{~km}$ were reduced compared to cold stadials C19 and C20, yet there was still vigorous near-bottom current activity at $\sim 1.8 \mathrm{~km}$ depth on BOR (notwithstanding the brief interval of D-O 18). These changes can be viewed as a further shoaling of the fast flowing WBUC at the onset of MIS 4. Benthic $\delta^{13} \mathrm{C}$ data from Site 1055 (Figure 3a) suggest a strong influence of nutrient-depleted, northern-sourced water throughout MIS 4 at $1.8 \mathrm{~km}$, with the exception of a brief interval of more nutrient-enriched water at $\sim 68.5-70 \mathrm{ka}$. Based on the combined flow speed and $\delta^{13} \mathrm{C}$ data, we therefore suggest that strong flow of northern-sourced water at depths $<2 \mathrm{~km}$ occurred at BOR throughout MIS 4, with a slight weakening and/or shoaling during HS6. This shallow northern-sourced water mass is analogous to "Glacial North Atlantic Intermediate Water" (GNAIW) [Curry and Oppo, 2005]. The observation of a shallow but active WBUC exporting GNAIW to the global ocean is consistent with recent sedimentary protactinium-thorium ratio $\left({ }^{231} \mathrm{~Pa} /{ }^{230} \mathrm{Th}\right)$ evidence from the Northeast Atlantic during MIS 4 [Guihou et al., 2011], and model results that suggest an active overturning cell extending up to $\sim 30-40^{\circ} \mathrm{N}$ and reaching depths of $\sim 1-2 \mathrm{~km}$ during particularly cold North Atlantic intervals [Stouffer et al., 2006; Renold et al., 2010].

[28] The regime shift at the onset of MIS 4, from a stadial/ interstadial to glacial-style of circulation may be related to the rapid growth of continental ice sheets that caused a sea-level drop of $\sim 40-60 \mathrm{~m}$ between $\sim 74$ and $70 \mathrm{ka}$, i.e., at the MIS 5a/4 boundary [Clark et al., 1993; Svendsen et al., 2004; Thompson and Goldstein, 2006]. Larger ice-sheets could have affected deep-water formation via greater discharge of icebergs and associated freshwater, as suggested by records of ice-rafted detritus [Chapman and Shackleton, 1999]. Alternatively, or in combination with changes in freshwater input, the growth of the Laurentide Ice Sheet (LIS) is likely to have altered atmospheric circulation and hence wind stress, air-sea cooling, and evaporationprecipitation over the North Atlantic [Hofer et al., 2012], all of which may have affected deep-water formation [Keigwin et al., 1991]. Important feedback mechanisms involving seaice may have amplified these effects, leading to a possible cooling-induced threshold behavior of North Atlantic deep convection [Knorr and Lohmann, 2007]. Plausibly, the thermal threshold and the location of convection sites depended on the growth of the LIS and the resultant wind stress changes, causing a switch in deep-water formation to a glacial mode of operation [Oka et al., 2012]. Reconstruction of an abrupt increase in polar water/sea-ice extent in the North Atlantic during the onset of MIS 4 (Figure 5) is consistent with this scenario [Bond et al., 1993]. It is also important to consider that coupling between circum-North Atlantic icesheets and ocean circulation is probably a two-way process, with ice-sheet growth itself also being sensitive to shifts in ocean circulation and resultant atmospheric circulation changes [e.g., Ruddiman and McIntyre, 1979; Broecker and Denton, 1989; Clark et al., 2001; Khodri et al., 2001; Timmermann et al., 2010]. Because of the aforementioned feedbacks between ice-sheet growth and ocean circulation, it is not obvious which process should have proceeded first. Improved constraints on the timing of the abrupt sea-level drop across the MIS $5 \mathrm{a} / 4$ transition will be required to determine the precise phasing of these events.

\subsection{Controls on Geostrophic Flow}

[29] The relative flow speed changes reported in this study are consistent with our understanding of changes in deep water formation patterns, and we have inferred that faster flow was driven by a greater production of the WBUC source waters (NADW/GNAIW/SSW) at different times. However, local geostrophic flow speed can change not only because of changes in the production rate of source water masses but also through changes in the density of the water masses, which alters the local density gradient [e.g., Knauss, 1997; McCave et al., 2005]. 


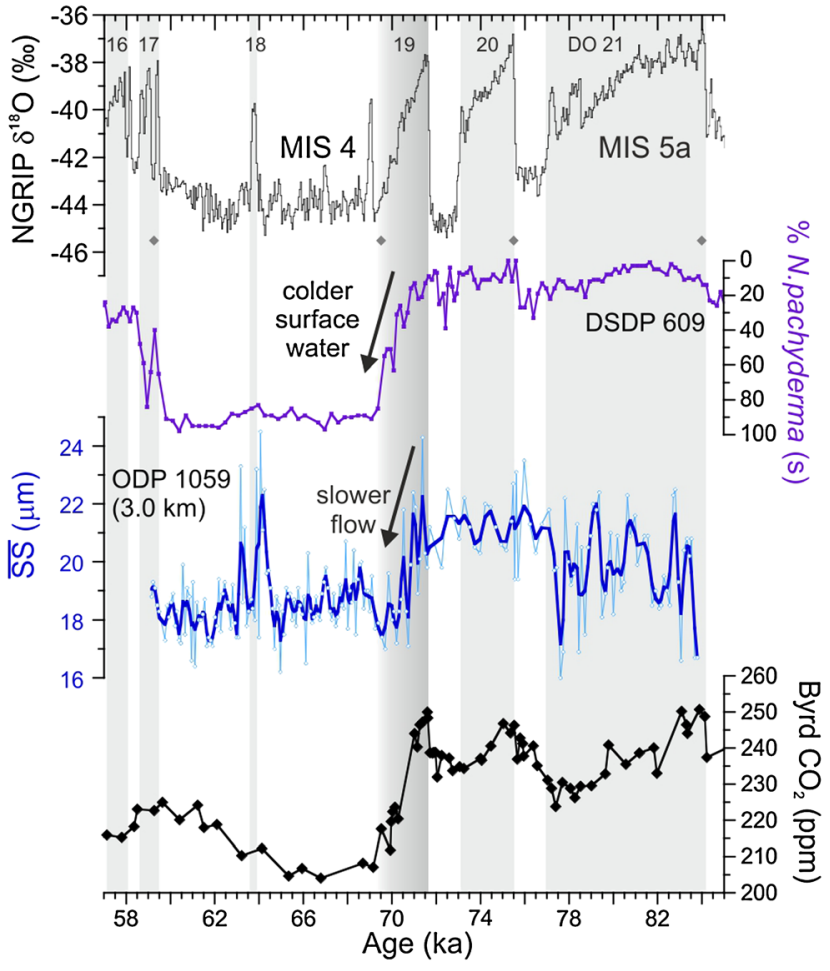

Figure 5. Proxy record indicating the timing of flow speed changes at Site 1059 (BOR, $\sim 3 \mathrm{~km}$ ) in comparison to NGRIP $\delta^{18} \mathrm{O}$, atmospheric $\mathrm{CO}_{2}$ levels as recorded in the Byrd Antarctic ice-core [Ahn and Brook, 2008] and \% Neogloboquadrina pachyderma (sinistral) as a proxy for the presence of cold, polar surface water in the North Atlantic [Bond et al., 1993], placed on the NGRIP age model using tie-points indicated by gray diamonds. The abrupt sea-level drop associated with the MIS $5 \mathrm{a} / 4$ transition occurred between $\sim 74 \mathrm{ka}$ and $\sim 70 \mathrm{ka}$ [Thompson and Goldstein, 2006].

[30] We are unable to assess past changes in deep water density gradients with sufficient accuracy to determine the extent to which this may have contributed to the observed flow speed changes. Benthic $\delta^{18} \mathrm{O}$ data has been used as an approximate indicator of density [Lynch-Stieglitz et al., 1999] in warmer upper ocean waters. However, at temperatures typical of the deep ocean, density, and $\delta^{18} \mathrm{O}$ are not closely coupled. Furthermore, benthic $\delta^{18} \mathrm{O}$ at deep water sites may also be affected by the influence of brine formation processes during glacial intervals, altering the seawater $\delta^{18} \mathrm{O}$-salinity relationship of the deep Atlantic [Adkins et al., 2002], and potentially causing anomalously light benthic $\delta^{18} \mathrm{O}$.

[31] Regardless, this study clearly documents the response of the WBUC to abrupt climate change and we favor interpretation of the flow speed variability in terms of a dominant influence of changes in the production rates of NADW/GNAIW/SSW. This is because results from model studies, as well as information provided from other kinematic proxies (e.g., ${ }^{231} \mathrm{~Pa} /{ }^{230} \mathrm{Th}$ and ${ }^{14} \mathrm{C}$ ), suggest strong export of GNAIW during the LGM [Yu et al., 1996; McManus et al., 2004; Gherardi et al., 2009] and MIS 4 [Guihou et al., 2011] and rapid advection of SSW from the
Southern Ocean to the North Atlantic during the LGM [Robinson et al., 2005; Negre et al., 2010].

\subsection{Implications for Atmospheric $\mathrm{CO}_{2}$}

[32] The data presented in this study show that a change in circulation regime occurred during the climate deterioration of D-O 19, so that by the end of D-O 19, circulation was operating in a glacial mode, distinct from that of earlier stadials. The timing of this transition is captured by $\overline{S S}$ data from site ODP 1059 (Figure 5), which is well placed to detect the switch to the shallow glacial mode of circulation. A similar trend is also recorded at Site 1060 (Figure 4), and the shallow Site 1055 detects an increase in flow speed at the end of D-O 19 due to this shoaling. Previous model studies suggest that a switch to shallow but vigorous GNAIW circulation may be an important contributor (perhaps by as much as $\sim 15-30 \mathrm{ppm}$ ) to the total $\sim 90$ ppm glacial drawdown of atmospheric $\mathrm{CO}_{2}$, through mechanisms involving the storage of DIC in the deep ocean and via feedbacks including deep sea carbonate dissolution [Brovkin et al., 2007; Ahn and Brook, 2008; Hain et al., 2010; Sigman et al., 2010; Brovkin et al., 2012; Kwon et al., 2012]. The results of this study demonstrate that the timing of this NADW-to-GNAIW transition is consistent with it contributing to the abrupt $\sim 40$ ppm decrease in atmospheric $\mathrm{CO}_{2}$ that had occurred by the end of D-O 19 [Ahn and Brook, 2008] and marked the onset of full glacial conditions.

\section{Concluding Remarks}

[33] We have shown that the flow speed structure of the WBUC underwent systematic changes in response to abrupt climate events during the MIS $5 \mathrm{a} / 4$ glacial inception. Physical changes in circulation were associated with basinwide variability in deep ocean chemistry, likely caused by changes in the mode of deep water formation. The development of full glacial conditions associated with the transition into MIS 4 was associated with a shift to a shallow mode of GNAIW circulation, perhaps related to the expansion of the LIS and its impacts on deep water formation. This shallow GNAIW circulation regime has been identified by previous studies as an important contributor to the drawdown of atmospheric $\mathrm{CO}_{2}$ during glacial inception.

[34] Further work needs to be conducted to determine whether the WBUC responded in a similar manner to D-O events throughout MIS 3 and into the Holocene. This is especially important in light of recent geochemical studies that suggest episodic ventilation of the deep North Atlantic by northern sourced waters during MIS 2 and HS1, despite the absence of significant contemporaneous warming events in Greenland climate records [Gutjahr and Lippold, 2011; Thornalley et al., 2011]. Existing grain size data from $\sim 3.5 \mathrm{~km}$ depth on BOR during MIS 3 [Hoogakker et al., 2007] indicate a pattern that is broadly consistent with our observations from MIS 5a/4, although as we have shown here, a complete depth transect is required to fully elucidate the response of the WBUC. As suggested by Hoogakker et al. [2007], and demonstrated in this study for D-O events $18-21$, it is likely that only BOR sites shallower than $\sim 2.5 \mathrm{~km}$ water depth will have flow speed records that display clear D-O variability. 
[35] Acknowledgments. We thank Rebecca Pyne for laboratory assistance, Ule Ninneman for benthic stable isotope analyses of severa small samples in Site 1063, and Lloyd Keigwin for discussions. We thank two anonymous reviewers and Associate Editor Elisabeth Michel for their constructive comments, which helped improve this work. This research used samples provided by the Ocean Drilling Program (ODP). ODP is sponsored by the U.S. National Science Foundation (NSF) and participating countries under management of Joint Oceanographic Institutions (JOI), Inc. This work was supported by the Natural Environment Research Council (NERC, UK) grants NE/F002734/1, NE/I006370/1 and NE/G004021/1. We also thank the Comer Science and Education Foundation and the Leverhulme Trust for financial support.

\section{References}

Adkins, J. F., K. McIntyre, and D. P. Schrag (2002), The salinity, temperature, and $\delta^{18} \mathrm{O}$ of the glacial deep ocean, Science, 298, 1769-1773.

Ahn, J., and E. J. Brook (2008), Atmospheric CO2 and climate on millennial time scales during the last glacial period, Science, 322, 83-85, doi:10.1126/ science. 1160832 .

Bard, E. (2001), Paleoceanographic implications of the difference in deepsea sediment mixing between large and fine particles, Paleoceanography, $16,235-239$.

Barker, S., G. Knorr, M. J. Vautravers, P. Diz, and L. C. Skinner (2010), Extreme deepening of the Atlantic overturning circulation during deglaciation, Nat. Geosci., 3, 567-571, doi:10.1038/NGEO921.

Barker, S., et al. (2011), 800,000 Years of Abrupt Climate Variability, Science, 334, 347-351, doi:10.1126/science.1203580.

Bianchi, G. G., M. Vautravers, and N. J. Shackleton (2001), Deep flow variability under apparently stable North Atlantic Deep Water production during the last interglacial of the subtropical NW Atlantic, Paleoceanography, 16, 306-316.

Bond, G., et al. (1993), Correlations between climate records from the North Atlantic sediments and Greenland ice, Nature, 365, 143-147.

Bower, A. S., and H. D. Hunt (2000), Lagrangian observations of the deep western boundary current in the North Atlantic Ocean. part I: Large-scale pathways and spreading rates, J. Phys. Oceanogr., 30, 764-783.

Broecker, W. S., and G. H. Denton (1989), The role of ocean-atmosphere reorganizations in glacial cycles, Geochim. Cosmochim. Acta, 53, $2465-2501$.

Brovkin, V., A. Ganopolski, D. Archer, and S. Rahmstorf (2007), Lowering of glacial atmospheric $\mathrm{CO}_{2}$ in response to changes in oceanic circulation and marine biogeochemistry, Paleoceanography, 22, doi:10.1029/ $2006 \mathrm{pa} 001380$.

Brovkin, V., A. Ganopolski, D. Archer, and G. Munhoven (2012), Glacial $\mathrm{CO} 2$ cycle as a succession of key physical and biogeochemical processes, Clim. Past, 8, 251-264, doi:10.5194/cp-8-251-2012.

Chapman, M. R., and N. J. Shackleton (1999), Global ice-volume fluctuations, North Atlantic ice-rafting events, and deep-ocean circulation changes between 130 and $70 \mathrm{ka}$, Geology, 27, 795-798.

Clark, P. U., et al. (1993), Initiation and development of the Laurentide and Cordilleran ice sheets following the last interglaciation, Quat. Sci. Rev., $12,79-114$

Clark, P. U., S. J. Marshall, G. K. C. Clarke, S. W. Hostetler, J. M Licciardi, and J. T. Teller (2001), Freshwater forcing of abrupt climate change during the last glaciation, Science, 293, 283-287.

Cleroux, C., E. Cortijo, J. C. Duplessy, and R. Zahn (2007), Deep-dwelling foraminifera as thermocline temperature recorders, Geochem. Geophys. Geosyst., 8, doi:10.1029/2006GC001474.

Curry, W. B., and D. W. Oppo (2005), Glacial water mass geometry and the distribution of $\delta^{13} \mathrm{C}$ of $\Sigma \mathrm{CO}_{2}$ in the western Atlantic Ocean, Paleoceanography, 20, doi:10.1029/2004PA001021.

Dickson, R. R., and J. Brown (1994), The production of North Atlantic deep water-sources, rates, and pathways, J. Geophys. Res.-Oceans, 99, 12319-12341.

Evans, H. K., I. R. Hall, G. G. Bianchi, and D. W. Oppo (2007), Intermediate water links to deep western boundary current variability in the subtropical NW Atlantic during marine isotope stages 5 and 4, Paleoceanography, 22, doi:10.1029/2006pa001409.

Evans, H. K., and I. R. Hall (2008), Deepwater circulation on Blake Outer Ridge (western North Atlantic) during the Holocene, younger dryas, and last glacial maximum, Geochem. Geophys. Geosyst., 9, doi:10.1029/ $2007 \mathrm{gc} 001771$.

Flood, R. D. (1994), Abyssal bedforms as indicators of changing bottom current flow-examples from the US east-coast continental rise, Paleoceanography, 9, 1049-1060.

Ganopolski, A., and S. Rahmstorf (2001), Rapid changes of glacial climate simulated in a coupled climate model, Nature, 409, 153-158.

Gebbie, G., and P. Huybers (2011), How is the ocean filled? Geophys. Res. Lett., 38, doi:10.1029/2011g1046769.
Gherardi, J.-M., et al. (2009), Glacial-interglacial circulation changes inferred from ${ }^{231} \mathrm{~Pa} /{ }^{230} \mathrm{Th}$ sedimentary record in the North Atlantic region, Paleoceanography, 24, doi:10.1029/2008PA001696.

Giosan, L., et al. (2001), High-resolution carbonate content estimated from diffuse spectral reflectance for Leg 172 sites. In Proc. ODP, Sci. Results, edited by L. D. Keigwin, D. Rio, G. D. Acton, and E. Arnold, 172, 1-12. Grüztner, J., et al. (2002), Astronomical age models for Pleistocene drift sediments from the western North Atlantic (ODPs 1055-1063), Mar. Geol., 189, 5-23.

Guihou, A., et al. (2011), Enhanced Atlantic meridional overturning circulation supports the last glacial inception, Quat. Sci. Rev., 30, 1576-1582, doi:10.1016/j.qua.scirev.2011.03.017.

Gutjahr, M., and J. Lippold (2011), Early arrival of southern source water in the deep North Atlantic prior to Heinrich event 2, Paleoceanography, 26, doi:10.1029/2011pa002114.

Hagen, S., and L. D. Keigwin (2002), Sea-surface temperature variability and deep water reorganisation in the subtropical North Atlantic during isotope stage 2-4, Mar. Geol., 189, 145-162.

Hain, M. P., D. M. Sigman, and G. H. Haug (2010), Carbon dioxide effects of Antarctic stratification, North Atlantic intermediate water formation, and subantarctic nutrient drawdown during the last ice age: Diagnosis and synthesis in a geochemical box model, Global Biogeochem. Cycles, 24, doi:10.1029/2010gb003790.

Hall, I. R., I. N. McCave, N. J. Shackleton, G. P. Weedon, and S. E. Harris (2001), Intensified deep Pacific inflow and ventilation in Pleistocene glacial times, Nature, 412, 809-812.

Hall, I. R., and J. Becker (2007), Deep western boundary current variability in the subtropical northwest Atlantic Ocean during marine isotope stages 12-10, Geochem. Geophys. Geosyst., 8, doi:10.1029/2006gc001518.

Hall, I. R., K. P. Boessenkool, S. Barker, I. N. McCave, and H. Elderfield (2010), Surface and deep ocean coupling in the subpolar North Atlantic during the last 230 years, Paleoceanography, 25, PA2101, doi:10.1029/ 2009PA001886.

Hall, I. R., H. K. Evans, and D. J. R. Thornalley (2011), Deep water flow speed and surface ocean changes in the subtropical North Atlantic during the last deglaciation, Global Planet. Change, 79, 255-263, doi:10.1016/ j.gloplacha.2010.12.001.

Haskell, B. J., T. C. Johnson, and W. J. Showers (1991), Fluctuations in deep western North Atlantic circulation on the Blake Outer Ridge during the last deglaciation, Paleoceanography, 6, 12-31.

Haskell, B. J., and T. C. Johnson (1993), Surface sediment response to deep-water circulation on the Blake Outer Ridge, Western North Atlantic - Paleoceanographic implications, Sediment. Geol., 82, 133-144.

Hofer, D., R. R. Raible, A. Dehnert, and J. Kuhlemann (2012), The impact of different glacial boundary conditions on atmospheric dynamics and precipitation in the North Atlantic region, Clim. Past, 8, 935-949, doi:10.5194/cp-8-935-2012.

Hoogakker, B. A. A., I. N. McCave, and M. J. Vautravers (2007), Antarctic link to deep flow speed variation during marine isotope stage 3 in the western North Atlantic, Earth Planet. Sci. Lett., 257, 463-473, doi:10.1016/j.epsl.2007.03.003.

Johns, E., R. A. Fine, and R. L. Molinari (1997), Deep flow along the western boundary south of the Blake Bahama Outer Ridge, J. Phys. Oceanogr., 27, 2187-2208.

Johnson, T. C., E. L. Lynch, W. J. Showers, and N. C. Palczuk (1988), Pleitocene fluctuations in the western boundary undercurrent on the Blake Outer Ridge, Paleoceanography, 3, 191-207.

Keigwin, L. D., and G. A. Jones (1989), Glacial-Holocene stratigraphy, chronology, and paleoanographic observations on some North-Atlantic sediment drifts, Deep-Sea Res. Part A, 36, 845-867.

Keigwin, L. D., G. A. Jones, and S. Lehman (1991), Deglacial meltwater discharge, North Atlantic deep circulation, and abrupt climate change, J. Geophys. Res., 96, 16811-16826.

Keigwin, L. D., and G. A. Jones (1994), Western North Atlantic evidence for millennial-scale changes in ocean circulation and climate, J. Geophys. Res., 99, 12,397-12,410.

Keigwin, L. D., W. B. Curry, S. J. Lehman, and S. Johnsen (1994), The role of the deep ocean in North Atlantic climate change between $70 \mathrm{kyr}$ and 130 kyr ago, Nature, 371, 323-326.

Keigwin, L. D. (1996), The Little Ice Age and Medieval Warm Period in the Sargasso Sea, Science, 274, 1504-1508.

Keigwin, L. D., and E. A. Boyle (1999), Surface and deep ocean variability in the northern Sargasso Sea during marine isotope stage 3, Paleoceanography, 14, 164-170.

Khodri, M, Y Leclainche, G. Ramstein, P. Braconnot, O. Marti, and E. Cortijo (2001), Simulating the amplification of orbital forcing by ocean feedbacks in the last glaciation, Nature, 410, 570-574.

Kissel, C. C. Laj, A. M. Piotrowski, S. L. Goldstein, and S. R. Hemming (2008), Millennial-scale propagation of Atlantic deep waters to the glacial Southern Ocean, Paleoceanography, 23, doi:10.1029/2008pa001624.

Knauss, J. A. (1997), Introduction to Physical Oceanography, 2nd ed., Prentice Hall, Princeton, NJ, 309 pp. 


\section{THORNALLEY ET AL.: WBUC VARIABILITY DURING MIS 5A/4}

Knight, J. R., R. J. Allan, C. K. Folland, M. Vellinga, and M. E. Mann (2005), A signature of persistent natural thermohaline circulation cycles in observed climate, Geophys. Res. Lett., 32, doi:10.1029/2005GL024233.

Knorr, G., and G. Lohmann (2007), Rapid transitions in the Atlantic thermohaline circulation triggered by global warming and meltwater during the last deglaciation, Geochem. Geophys. Geosyst., 8 , doi:10.1029/2007GC001604.

Kwon, E. Y., M. P. Hain, D. M. Sigman, E. D. Galbraith, J. L. Sarmiento, and J. R. Toggweiler (2012), North Atlantic ventilation of "southernsourced" deep water in the glacial ocean, Paleoceanography, 27, doi:10.1029/2011PA002211.

Lea, D. W., D. K. Pak, L. C. Peterson, and K. A. Hughen (2003), Synchroneity of tropical and high-latitude Atlantic temperatures over the last glacial termination, Science, 301, 1361-1364, doi:10.1126/science.1088470.

Ledbetter, M. T., and D. A. Johnson (1976), Increased transport of Antarctic bottom water in Vema Channel during Last Ice Age, Science, 194, 837-839.

Ledbetter, M. T., and W. L. Balsam (1985), Paleoceanography of the deep western boundary undercurrent on the North American continental margin for the past 25,000 yr, Geology, 13, 181-184.

Ledbetter, M. T. (1986), A late Pleistocene time-series of bottom-current speed in the Vema Channel, Palaeogeogr. Palaeoclimatol. Palaeoecol., $53,97-105$.

Lynch-Stieglitz, J., W. B. Curry, and N. Slowey (1999), A geostropic transport estimate for the Florida current from the oxygen isotope composition of benthic foraminifera, Paleoceanography, 14, 360-373.

Masse, L., J. C. Faugeres, M. Bernat, A. Pujos, and M. L. Mezerais (1994), A 600,000-year record of Antarctic bottom water activity inferred from sediment textures and structures in a sediment core from the southern Brazil Basin, Paleoceanography, 9, 1017-1026.

McCave, I. N., C. D. Hollister, E. P. Laine, P. F. Lonsdale, and M. J. Richardson (1982), Erosion and deposition on the eastern margin of the Bermuda Rise in the Late Quaternary, Deep-Sea Res. Part A, 29, 535-561.

McCave, I. N., B. Manighetti, and S. G. Robinson (1995), Sortable silt and fine sediment size/composition slicing: Parameters for palaeocurrent speed and palaeoceanography, Paleoceanography, 10, 593-610.

McCave, I. N., T. Kiefer, D. J. R. Thornalley, and H. Elderfield (2005), Deep flow in the Madagascar-Mascarene Basin over the last 150,000 years, Philos. Trans. R. Soc. London Ser. A, 363, 81-99, doi:10.1098/ rsta.2004.1480.

McCave, I. N., and I. R. Hall (2006), Size sorting in marine muds: Processes, pitfalls, and prospects for paleoflow-speed proxies, Geochem. Geophys. Geosyst., 7, doi:10.1029/2006gc001284.

McManus, J. F., R. Francois, J. Gherardi, L. D. Keigwin, and S. Brown-Leger (2004), Collapse and rapid resumption of Atlantic meridional circulation linked to deglacial climate changes, Nature, 428, 834-837, doi:10.1038/ nature 02494

Negre, C., et al. (2010), Reversed flow of Atlantic deep water during the Last Glacial Maximum, Nature, 468, 84-88, doi:10.1038/nature09508.

NGRIP members (2004), High-resolution record of Northern Hemisphere climate extending into the last interglacial period, Nature, 431, 147-151.

Ohkouchi, N., T. I. Eglington, L. D. Keigwin, and J. M. Hayes (2002), Spatial and temporal offsets between proxy records in a sediment drift, Science, 298, 1224-1227, doi:10.1126/science.1075287.

Oka, A., H. Hasumi, and A. Abe-Ouchi (2012), The thermal threshold of the Atlantic meridional overturning circulation and its control by wind stress forcing during glacial climate, Geophys. Res. Lett., 39, doi:10.1029/ 2012GL051421.

Piotrowski, A. M., S. L. Goldstein, S. R. Hemming, and R. G. Fairbanks (2005), Temporal relationships of carbon cycling and ocean circulation at glacial boundaries, Science, 307, 1933-1937, doi:10.1126/science.1104883.

Renold, M., C. C. Raible, M. Yoshimori, and T. F. Stocker (2010), Simulated resumption of the North Atlantic meridional overturning circulation - Slow basin-wide advection and abrupt local convection, Quat. Sci. Rev., 29, 101-112, doi:10.1016/j.quascirev.2009.11.005
Roberts, N. L., A. M. Piotrowski, J. F. McManus, and L. D. Keigwin (2010), Synchronous deglacial overturning and water mass source changes, Science, 327, 75-78, doi:10.1126/science.1178068.

Robinson, L. F., et al. (2005), Radiocarbon variability in the western North Atlantic during the last deglaciation, Science, 310, 1469-1473, doi:10.1126/science. 1114832 .

Ruddiman, W. F., and A. McIntyre (1979), Warmth of the sub-polar North Atlantic Ocean during northern hemisphere ice-sheet growth, Science, 204, 173-175

Sachs, J. P., and S. J. Lehman (1999), Subtropical North Atlantic temperatures 60,000 to 30,000 years ago, Science, 286, 756-759.

Sarnthein, M. S., et al. (2000), in The Northern North Atlantic: A Changing Environment, edited by P. Ritzrau, W. Schafer, W. Schluter, and J. Thiede, 365-410, Springer.

Schmidt, M. W., M. J. Vautravers, and H. J. Spero (2006), Rapid subtropical North Atlantic salinity oscillations across Dansgaard-Oeshger cycles, Nature, 443, 561-564, doi:10.1038/nature05121.

Schmittner, A. (2003), Southern Ocean sea ice and radiocarbon ages of glacial bottom waters, Earth Planet. Sci. Lett., 213, 53-62, doi:10.1016/ S0012-821X(03)00291-7.

Shackleton, N. J., M. A. Hall, and E. Vincent (2000), Phase relationships between millennial-scale events 64,000-24,000 years ago, Paleoceanography, 15, 565-569.

Shin, S. I., Z. G. Liu, B. L. Otto-Bliesner, J. E. Kutzbach, and S. J. Vavrus (2003), Southern Ocean sea-ice control of the glacial North Atlantic thermohaline circulation, Geophys. Res. Lett., 30, doi:10.1029/2002gl015513.

Sigman, D. M., M. P. Hain, and G. H. Haug (2010), The polar ocean and glacial cycles in atmospheric $\mathrm{CO}_{2}$ concentration, Nature, 466 , 47-55, doi:10.1038/nature09149.

Stahr, F. R., and T. B. Sanford (1999), Transport and bottom boundary layer observations of the North Atlantic deep western boundary current at the Blake Outer Ridge, Deep-Sea Res. Part II, 46, 205-243.

Stommel, H. (1958), The Abyssal Circulation, Deep-Sea Res., 5, 80-82.

Stouffer, R. J., et al. (2006), Investigating the causes of the response of the thermohaline circulation to past and future climate changes, J. Climate, 19, 1365-1387, doi: http://dx.doi.org/101175/Jcl13689.1.

Svendsen, J. I., et al. (2004), Late quaternary ice sheet history of northern Eurasia, Ouat. Sci. Rev., 23, 1229-1271, doi:10.1016/j.quascirev.2003.12.008.

Swallow, J. C., and L. V. Worthington (1961), An observation of a deep countercurrent in the western North Atlantic, Deep-Sea Res., 8, 1-19.

Thompson, W. G., and S. L. Goldstein (2006), A radiometric calibration of the SPECMAP timescale, Quat. Sci. Rev., 25, 3207-3215, doi:10.1016/ j.quascirev.2006.02.007.

Thornalley, D. J. R., S. Barker, W. Broecker, H. Elderfield, and I. N. McCave (2011), The deglacial evolution of North Atlantic deep convection, Science, 331, 202-205, doi:10.1126/science.1196812.

Timmermann, A., J. Knies, O. E. Timm, A. Abe-Ouchi, and T. Friedrich (2010), Promotion of glacial ice sheet buildup 60-115 kyr B.P. by precessionally paced Northern Hemispheric meltwater pulses, Paleoceanography, 25, doi:10.1029/2010pa001933.

Vautravers M. J., N. J. Shackleton, C. Lopez-Martinez, and J. O. Grimalt (2004), Gulf stream variability during marine isotope stage 3 Paleoceanography, 19, doi:10.1029/2003PA000966.

Vellinga, M., and R. A. Wood (2002), Global climatic impacts of a collapse of the Atlantic thermohaline circulation, Clim. Chang., 54, 251-267.

Weatherly, G. L., and E. A. Kelley (1984), Two views of the cold filament, J. Phys. Oceanogr., 15, 68-81.

Yokokawa, M., and S. O. Franz (2002), Changes in grain size and magnetic fabric at Blake-Bahama outer ridge during the late Pleistocene (marine isotope stages 8-10), Mar. Geol., 189, 123-144.

Yu, E.-F., R. Francois, and M. P. Bacon (1996), Similar rates of modern and last-glacial ocean thermohaline circulation inferred from radiochemical data, Nature, 379, 689-694. 